\title{
Review: \\ Economic impacts of the invasive species water hyacinth (Eichhornia crassipes): Case study of Rawapening Lake, Central Java, Indonesia
}

\author{
ANINDA MAULIDYNA ${ }^{1}$, FITRI ALICIA ${ }^{1}$, HERLINA NOOR AGUSTIN ${ }^{1}$, INDAH ROSITA DEWI ${ }^{1}$, \\ ITSNA NURHIDAYAH ${ }^{1}$, ARU DEWANGGA ${ }^{1}$, LIA KUSUMANINGRUM ${ }^{1}$, GILANG DWI NUGROHO ${ }^{2}$, \\ JUMARI $^{3}$, AHMAD DWI SETYAWAN ${ }^{1,4, \bullet}$ \\ ${ }^{1}$ Department of Environmental Science, Faculty of Mathematics and Natural Sciences, Universitas Sebelas Maret. Jl. Jend. Urip Sumoharjo No. 179 , \\ Surakarta 57128, Central Java, Indonesia.Tel.: +62-271-663375, •email: volatileoils@ gmail.com \\ ${ }^{2}$ Biodiversitas Study Club, Department of Biology, Faculty of Mathematics and Natural Sciences, Universitas Sebelas Maret. J1. Ir. Sutami No. 36A, \\ Surakarta 57126, Central Java, Indonesia \\ ${ }^{3}$ Department of Biology, Faculty of Natural Science and Mathematics, Universitas Diponegoro. Jl. Prof. Soedarto, SH, Tembalang, Semarang 50275, \\ Central Java, Indonesia \\ ${ }^{4}$ Biodiversity Research Group, Universitas Sebelas Maret. J1. Ir. Sutami No. 36A, Surakarta 57126, Central Java, Indonesia
}

Manuscript received: 8 January 2001. Revision accepted: 19 June 2021.

\begin{abstract}
Maulidyna A, Alicia F, Agustin HN, Dewi IR, Nurhidayah I, Dewangga A, Kusumaningrum L, Nugroho GD, Jumari, Setyawan AD. 2021. Review: Economic impacts of the invasive species water hyacinth (Eichhornia crassipes): Case study of Rawapening Lake, Central Java, Indonesia. Intl J Bonorowo Wetlands 11: 18-31. Introduced species is defined as a conscious or unconscious effort to present a species of animal or plant into a new habitat. Introduced species have two pathways on their biogeographical distribution: becoming an invasive species or not becoming an invasive species. An introduced species that does not negatively impact the new habitat is not classified as an invasive species. In contrast, a species introduced that negatively impacts the new habitat is considered invasive. One problem that threatens freshwater ecosystems in Indonesia is the invasion of water hyacinth (Eichhornia crassipes). This introduced plant species can reproduce rapidly, both generatively and vegetatively, and form very dense masses in water bodies, such as swamps, lakes, rivers, and channels, including Rawapening Lake in Semarang District, Central Java Indonesia. This study is aimed to review the economic impacts of the invasive water hyacinth species in Rawapening Lake from two perspectives: the negative and the positive impacts so that feasible solutions can be developed. There are several negative impacts caused by water hyacinth in Rawapening Lake. The overgrown water hyacinth in the lake hinders the fishers in maneuvering the boats and fishing gears, reducing the fish catches. The extensive coverage of water hyacinth causes the reduction in soluble oxygen and blocks sunlight into the water, leading to the decline of the fish population. The rotten water hyacinth can obstruct the irrigation channels of the fields so that farmers cannot produce maximum rice harvests, and eradicating them would incur financial costs. On the other hand, there are also positive impacts of water hyacinth in Rawapening Lake. This plant can be used as raw materials to produce a variety of handicrafts in the form of bags, sandals, baskets, wallets, and furniture such as chairs and tables. Water hyacinth can also be processed in biogas production and organic fertilizers. Water hyacinth can remediate polluted water caused by heavy metals contamination with careful management. In short, economically, water hyacinth in Rawapening can be both beneficial and detrimental. Proper management of this species is necessary to maintain the sustainability of this aquatic environment.
\end{abstract}

Keywords: Economic impact, invasive plant, Rawapening Lake, water hyacinth

\section{INTRODUCTION}

Introduced species is defined as a conscious or unconscious effort to present a species of animal or plant into a new habitat. Introduced species have two pathways on their biogeographical distribution: becoming an invasive species or not becoming an invasive species. An introduced species which does not have a negative impact on the new habitat is not classified as an invasive species, while a species that is introduced and do have a negative impact on the new habitat is considered an invasive species (Caplat and Coutts 2011; van Wilgen and Richardson 2012; Gallardo et al. 2016; Schirmel et al. 2016; Courchamp et al. 2017; David et al. 2017; Thapa et al. 2018; Bartz and Kowarik 2019). The most noticeable impact of invasive species is the domination of habitat by the newly introduced species (Kumschick et al., 2015). The route of arrival and spread of invasive species can be caused by natural factors (e.g., storms, ocean currents, and climate change) and human factors, through the introduction and distribution, either intentionally (e.g., crops and pets) or unintentionally (e.g., trade, tourism, and transportation).

Nowadays, invasive species (either animals or plants) have spread to almost all types of ecosystems on earth, including mountain, lowland, terrestrial ecosystems, freshwater, and marine ecosystems, as well as archipelagic and continental realms (Mostert et al. 2013; Gallardo et al. 2015; Russel et al. 2017; Spatz et al. 2017). According to Llewelyn et al. (2011), in Australia found, the cane toad (Bufo marinus) is huge (up to $40 \mathrm{~cm}$ long), the so-called 
"Toadzilla" (after the term Godzilla monster). These frogs were initially imported from Hawaii to deal with the overgrowth of local frogs. However, it turns out that introducing this species into an invasive species threatens diversity in Australia because the local frogs are depleted, the cane toad continues to exist, and even thrives because there are no predators such as crocodiles and snakes that can survive after eating it. In Europe, Heracleum mantegazzianum, Lupinus polyphyllus, and Rosa rugosa are all invasive plants that can produce dominant stands with a cover of more than $90 \%$ (Thiele et al. 2011). In the Americas, there are Ampelopsis brevipedunculata, Cynanchum louiseae, and Ranunculus ficaria, which have a high invasive rate because their growth is very fast, beating the native species (Buerger et al. 2016). Then, South Africa can spend a lot of money dealing with invasive species such as Acacia mearnsii, Acacia saligna, Leptospermum laevigatum, Pinus halepensis Pinus pinaster, and Pinus radiata that interfere with local biodiversity in the Nature Reserve (Gaertner et al. 2016).

As many countries face globally, Asia, especially Indonesia, has emerging invasive species problems. One of the problems facing Indonesia is the uncontrollable spread of introduced plants. These plants species are often considered as weeds, and the most dangerous weed species are those which have high reproductive abilities and cause devastating impacts both ecologically and economically (Essl et al. 2011; McConnachie et al. 2012; Mkumbo and Marshall 2014; Srivastava et al. 2014; Arp et al. 2017; Essl et al. 2017; Huang et al. 2018). One invasive species in Indonesia is water hyacinth (Eichhornia crassipes).

The invasion of water hyacinth occurs in many aquatic ecosystems across Indonesia, one of which is in Rawapening Lake. The presence of water hyacinth is becoming dominant nowadays and causes the Rawapening Lake ecosystem to become unbalanced. The Uncontrolled growth of water hyacinth poses a significant risk to the aquatic ecosystem in Rawapening Lake (Gichuki et al., 2012; Dereje et al., 2017; Gaikwad and Gavande 2017; Degaga 2019; Madian et al. 2019; Prasetyo et al. 2021). This phenomenon occurs because of eutrophication, a condition of increasing the nutrient content in water, especially phosphorus (P) and excessive nitrogen (N) (Clout and Williams 2009; Uwadiae et al. 2011; Zan et al. 2011; Arthaud et al. 2012; Coetzee and Hill 2012; Sood et al. 2012; Patel 2012; Chislock et al. 2013; Grasset et al. 2016; Guignard et al. 2017). The uncontrolled growth of water hyacinth will cover the water surface in the lake and block light from entering the lake, which causes biota such as fish to experience a lack of oxygen and nutrients, leading to death and population reduction (Bornette and Puijalon 2011; Mironga et al. 2011; Güereña et al. 2015; Kamau et al. 2015; Gupta and Yadav 2020). On the abiotic factor, the invasion of water hyacinth in Rawapening Lake also causes silting in the bottom of the lake.

The ecological impacts of water hyacinth invasion in Rawapening Lake can inflict negative consequences on the economy of stakeholders who rely on the lake, such as fishermen. The study on the economic impact of water hyacinth invasion in Rawapening Lake is essential for water hyacinth eradication or management solutions. Therefore, this study is aimed to review the economic impacts of the invasive water hyacinth species in Rawapening Lake from two perspectives: the negative and the positive impacts, so that feasible solutions can be developed.

\section{THE CONTEXT OF STUDY AREA: RAWAPENING LAKE}

The context of this study is in the Rawapening Lake area, Semarang District, Central Java, Indonesia (Figure 1). This is a semi-natural lake with about 2,607 hectares administratively located in the subdistricts of Ambarawa, Bawen, Banyubiru, and Tuntang (Sudjarwo et al. 2014). Rawapening Lake is located approximately 45 kilometers south of Semarang City and 9 kilometers northwest of Salatiga City, in the golden triangle between Semarang, Solo, and Yogyakarta. The lake geographically is located at $7^{\circ} 04^{\prime}-7^{\circ} 30^{\prime}$ south latitude and $110^{\circ} 24^{\prime} 46^{\prime}-110^{\circ} 49^{\prime} 06^{\prime}$ ', east longitude, and it has an altitude of 460 meters above sea level.

Indonesia has ratified the Sustainable Development Goals (SDGs) and global communities for the 2015-2030 period (UNDP Indonesia 2015). One of the global agendas on the SDGs is to ensure the availability and sustainable management of water and sanitation for all. In line with this, Indonesia has developed the National Medium-Term Development Plan (RPJMN) for the 2020-2024 period, clearly stated in Chapter 7, namely building the environment, increasing disaster resilience, and climate change Rawapening Lake priority water ecosystems. This lake is protected explicitly in the maintenance, restoration, and conservation of natural resources and water ecosystems by Presidential Regulation No.18 (2020).

Rawapening Lake is utilized for various purposes, including water drinking sources, fisheries, agriculture, tourism, social and religious life, and hydroelectricity (Soeprobowati 2017). Historically, this lake was dammed by the Dutch Colonial Government in 1936 with a maximum water table area of 2,667 ha in the rainy season (November-April) and 1,650 ha in the dry season (MayOctober) (Sulastri et al. 2016). Currently, the lake is under intense pressures to exceed its capacity, which four prominent conditions can indicate, namely reduced fishery production, the rapid growth of aquatic plants, pollution of water sources and loss of endemic organisms, as well as silting and depletion of lakes area from its original state (Haryani 2013). Among such problems, the rapid growth of aquatic plants in Rawapening Lake is caused by the uncontrolled growth of water hyacinth. 

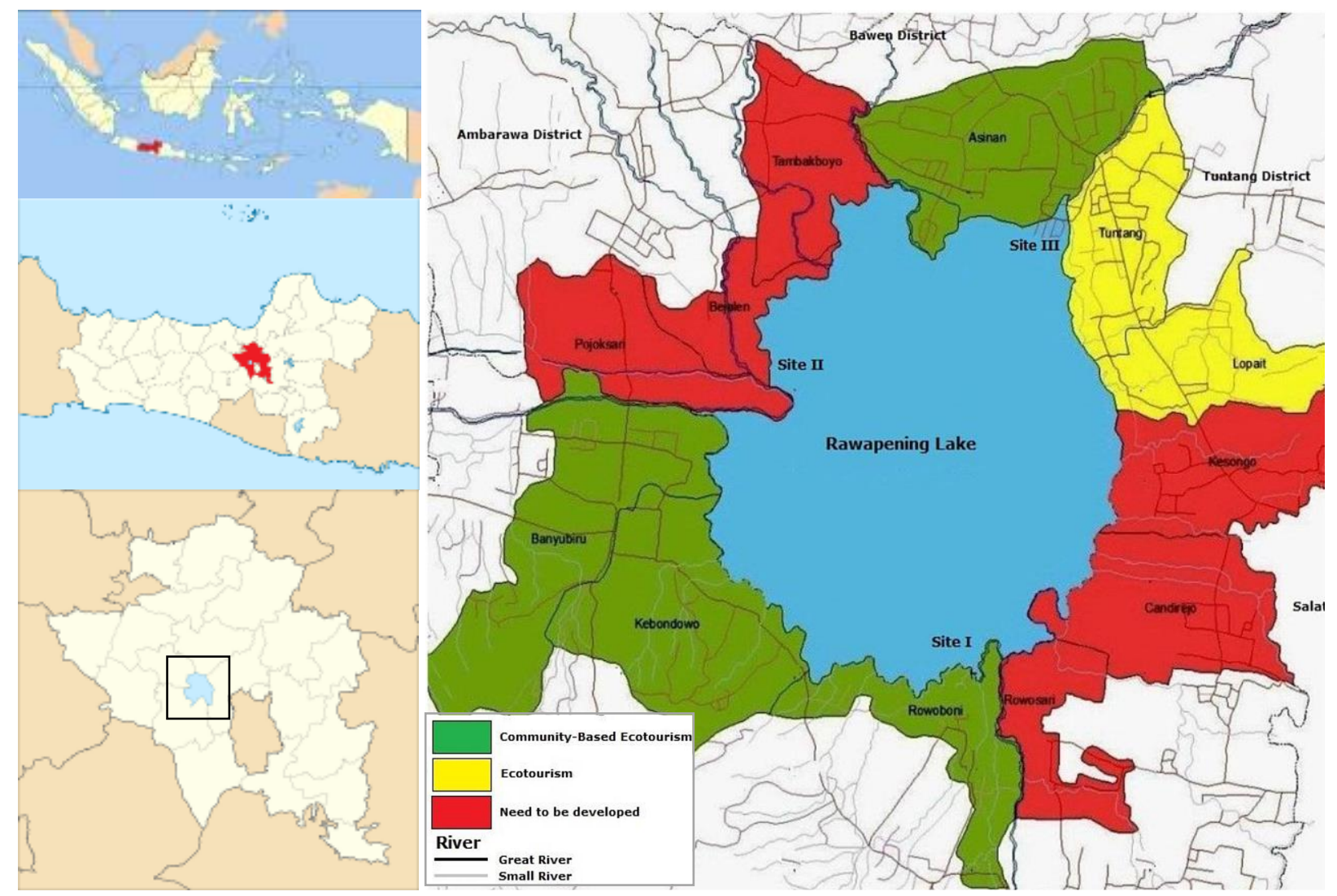

Figure 1. Map of the Rawapening Lake area, Semarang District, Central Java Province, Indonesia

\section{INVASIVE PLANTS: A BRIEF HISTORY OF WATER HYACINTH IN INDONESIA}

Flora is defined as a plant that grows and can spread from one area to another, which becomes its new habitat. A plant that historically grows in a particular area or habitat is known as native species. However, with the development of trade flows and transportation across countries and regions, there has been a change by allowing various species to move and cross long distances into new habitats as foreign species (Turbelin et al., 2017). In the context of Indonesia, the native flora is often so-called Flora Malesiana, and plant species other than Flora Malesiana are considered introduced or alien plant species.

The existence of introduced species can cause impacts in changes in the composition of local or native species. Introduced plants species can have a significant impact on an area, be it detrimental or beneficial (Kowarik et al. 2011; Lodge et al. 2012; Ricciardi et al. 2013; Simberloff 2013; Jeschke et al. 2014; Genovesi et al. 2015; Tanner et al. 2017; Hanley and Robert 2019). Several introduced plant species positively impact other species, ecosystems, and humans. Several other introduced plant species are invasive, potentially disturbing other species, ecosystems, and humans (Schlaepfer et al. 2011; Kapler et al. 2012; Blackburn et al. 2014; Roy et al. 2018; Epanchien-Niell 2017; Riley et al. 2018).

The difference between introduced and invasive species is that introduced species are not necessarily invasive species. However, all invasive species must be introduced (Gallardo et al. 2016; Schirmel et al. 2016; Courchamp et al. 2017; David et al. 2017; Thapa et al. 2018; Bartz and Kowarik 2019). Invasive species have several characteristics that make it easier for them to compete and over-dominates other species (Rakotoarisoa et al. 2015), including quick and mass reproduction biology, rapid growth and survival, ability to widespread, tolerance to a wide range of environmental conditions, ability to live with various types of food, and can cause damage to ecosystems (Pejchar and Mooney 2009; Vilà et al. 2011; Pyšek et al. 2012; Ricciardi et al. 2013; Gallardo et al. 2016; Schirmel et al. 2016; David et al. 2017; Foxcroft et al. 2017; Vilà and Hulme 2017). Invasive species can also cause socioeconomic damages (Bacher et al. 2018) or affect infrastructure (Booy et al. 2017). Furthermore, invasive species management usually requires considerable financial and personnel resources (Hoffmann and Broadhurst 2016).

There are several processes in the invasion of introduced plants that influences natural communities, including competition, which affect the ecological processes in an ecosystem (Coetzee et al. 2011, 2014; Tollington et al. 2015; Solfiyeni 2016). According to Kumschick et al. (2012) and Blackburn et al. (2014), the competition is related to the interaction between two or more species in a habitat that occurs because of the exact needs, so that they compete for habitat, air, water, food, sunlight and so on. This competition will impact the underperforming species to die, be eliminated, or move to 
another place. Thus, a strong invasion of the invasive plant can lead to a decrease in the population of the native plants and, in some instances, may cause local extinction.

Water hyacinth is a freshwater plant species first discovered accidentally by a botanist from Germany, Carl Friedrich Philipp von Martius, when he was doing an expedition in the Amazon River, Brazil, South America, in 1824 (Chunkao et al. 2012). Generally, water hyacinths live and grow above the wetland water surface and can also be grown among agricultural crops cultivated in wetlands. In 1894, during the occupation of the Bataaf Republic in the Dutch East Indies (now Indonesia), water hyacinth plants were first brought to Indonesia as a collection of aquatic plants (Ratnani. 2012). General Governor Thomas Stamford Raffles, who governed the Bataaf Republic in Indonesia, exported water hyacinth from Brazil, South America, and cultivated it in a pond in the Bogor Botanic Gardens (Lestari et al. 2018).

At first, water hyacinth was in great demand by Indonesians as an ornamental plant because it has flowers with purple and blue colors that are pretty striking, making it suitable as an ornamental plant for ponds. After all, it resembles a lotus plant (Figure 2) (Arham 2013). Water hyacinth plants can reproduce incredibly fast, so the presence of water hyacinth in the Bogor Botanical Garden pond has covered several existing water bodies. Due to the rapid growth (about 3\% per day), the water hyacinth was then dumped through the rivers around the Bogor Botanical Gardens, spreading into waterways, marshes, and lakes throughout Indonesia and Southeast Asia. The growth of water hyacinth is uncontrolled and very fast that this plant is considered an invasive weed (Patel 2012; Frezina 2013; Ilo et al. 2020).

Nowadays, water hyacinth has invaded many freshwater bodies across Indonesia, including lakes. Besides the biological traits related to the invasiveness of water hyacinth, the invasion of these plants is facilitated with the degraded conditions of biotic and abiotic factors of the lakes. The majority of lakes in Indonesia are currently facing environmental problems such as eutrophication, sedimentation, and a decrease in the lake area, one of the leading causes of which is the invasive growth of water hyacinth (Juma et al. 2014; Soeprobowati et al. 2016; Sulastri et al. 2016; Guignard et al. 2017; Sutadian et al. 2017).

\section{THE BIOLOGY OF WATER HYACINTH}

Water hyacinth (Eichhornia crassipes (Mart. and Zucc.) Solms; syn. Pontederia crassipes Mart.) belongs to the family Pontederiaceae. It is a floating weed in tropical and sub-tropical freshwater lakes and rivers, especially those enriched with organic matters. It grows in shallow freshwater wetlands and can create pure stands. An emergent perennial aquatic plant forms rosettes of thick and spongy leaves. Flowers appear on the spike-like flower stalks. Beneath the surface water, the plant has black, fibrous roots. Rosettes are often connected to the surface water by stolons roots develop at the base of each leaf and form a dense mass: usually $20-60 \mathrm{~cm}$ long, although it can extend up to $300 \mathrm{~cm}$. Periodically, axillary shoots develop as stolons, growing horizontally $10-50 \mathrm{~cm}$ before forming daughter plants. Vast populations of interconnected shoots can develop rapidly, although the stolons eventually die (Gopal 1987; Zhang and Guo 2017).

Plant sizes vary widely; seedlings have leaves only a few centimeters wide or in height, while mature plants with a good supply of nutrients can reach a height of $1 \mathrm{~m}$. Plants in an open habitat tend to have short, spreading petioles with marked swelling, whereas, in dense stands, they are taller, more erect, and with little or no swelling petioles. The plant system consists of individual shoots, each with ten broad leaves arranged in a spiral, separated by very short internodes. As individual shoots develop, older leaves die, leaving pieces of dead shoots with no leaves protruding downwards (Figure 2) (Gopal 1987; Zhang and Guo 2017).

The leaves are basal and straightforward, forming a rosette around the flower stalk. Leaves consist of petioles (often swollen, 2-5 cm thick) and blades (roughly round, kidney or ovoid-shaped, up to $15 \mathrm{~cm}$ ). The petiole base and subsequent leaves are flanked by $6 \mathrm{~cm}$ long stipules. Each petiole is short and consists mainly of a bulging ball that helps the plant float in the open state. The petioles become longer, thinner, and less inflated in more shady conditions. Leaf venation is parallel, and leaf margin is smooth (Figure 2) (Gopal 1987; Zhang and Guo 2017).

The inflorescences are loose, spike-like clusters of tiny lavender, resting on the erect stalk. Each flower has 6 petals. The inflorescences are spikes that develop from the apical meristem but tend to emerge laterally due to the rapid development of the axillary shot as a 'renewal' or 'continuation' shoot. Each spike, up to $50 \mathrm{~cm}$ high, has two bracts below it and has 8-15 sessile flowers (4-35 rarely). The bottom 5 petals are a solid shade of lilac or lavender, but the topmost petal has a bright yellow dot surrounded by a bluish "halo." Each flower has a perianth tube $1.5 \mathrm{~cm}$ long, developing into six light purple or purple lobes up to $4 \mathrm{~cm}$ long. The main lobe has a bright yellow, diamondshaped patch surrounded by deep purple. Once the inflorescences have fully emerged from the leaf midrib, all the flowers open together, starting at night, completing the process in the morning, and most often the following evening when the peduncle begins to bend. The flowers are tristylus. They have six stamens and one style. The fruit is a three celled capsules containing many tiny seeds. Each capsule can hold up to 450 small seeds, each measuring about 1 x 3 mm (Figure 2) (Gopal 1987; Zhang and Guo 2017)

Water hyacinth has a flexible morphology that easily adapts to habitats with specific physicochemical and biological characteristics, especially changes in root length, petiole length and shape, and shoot-root ratio. However, this macrophyte causes extensive damage due to its biology and function in aquatic ecosystems. Water hyacinth has morphological elasticity, speedy growth, changes in the chemical composition of various plant parts in multiple habitats, adaptive phenology for ecological invasion, and vegetative and sexual reproduction for persistent distribution. This aquatic perennial free-floating plant is a 
harmful, unique, useful, fast-growing, and constant invasive macrophyte. The root morphology plus the fast growth rate under suitable conditions allows one hectare of water surface to be covered entirely by water hyacinth every day (Penfound and Earle 1948; Zhang and Guo 2017).

Water hyacinth reproduces by seed, budding, fragmentation, and stolon production. Seeds may germinate within a few days or remain dormant for 15-20 years. They usually sink and stay dormant until periods of stress (drought). After re-flood, the seeds often germinate and renew the growth cycle (Gopal 1987; Westerdahl and Getsinger 1988; Barrett, 1989; Sharma et al. 2016; Mathur and Mathur 2017). Daughter plants grow from stolons, and doubling times have been reported to be 6-18 days. Water hyacinths multiply rapidly, float and spread easily, and quickly cover water bodies, resulting in poor water transparency. Therefore, water hyacinth competes with other aquatic plants (floating and submerged) and algae for mineral nutrients, sunlight, space, and other resources in natural waters (Masifwa et al. 2001; Villamagna and Murphy 2010).

\section{WATER HYACINTH IN RAWAPENING LAKE}

Rawapening Lake receives water from the springs of several mountains that flow through eight tributaries (UNEP 1999). The tributaries of the lake watershed flow through the catchment area, which is widely used for agriculture and urban development, is suspected as a source of increased sediment load and nutrient content in the lake. The land uses of water catchment area in Rawapening Lake include secondary forest $(12,661.65 \mathrm{ha})$, primary forest (593.48 ha), agriculture (8,974.48 ha) which consists of irrigated and non-irrigated agriculture, settlements (3,304.44 ha), plantations (480.30 ha), shrubs (529.55 ha), and water bodies (1,517.46 ha). Non-irrigated agriculture for vegetable cultivation in water catchment areas has caused erosion and sedimentation in lakes (Wuryanta and Paimin 2012).

Water hyacinth is very easy to find in Rawapening Lake because the water hyacinth population in this lake is very abundant. The speedy growth and spread of water hyacinth plants are probably due to eutrophication in Rawapening Lake waters, which can be influenced by several causes such as high levels of nutrients (nitrogen and phosphorus) and pesticides from agricultural waste, feed waste from livestock, factory waste, domestic waste, etc., that flowed into the water bodies of Rawapening Lake (Knoll et al. 2003; Soeprobowati et al. 2012; Verma and Sivappa 2017).

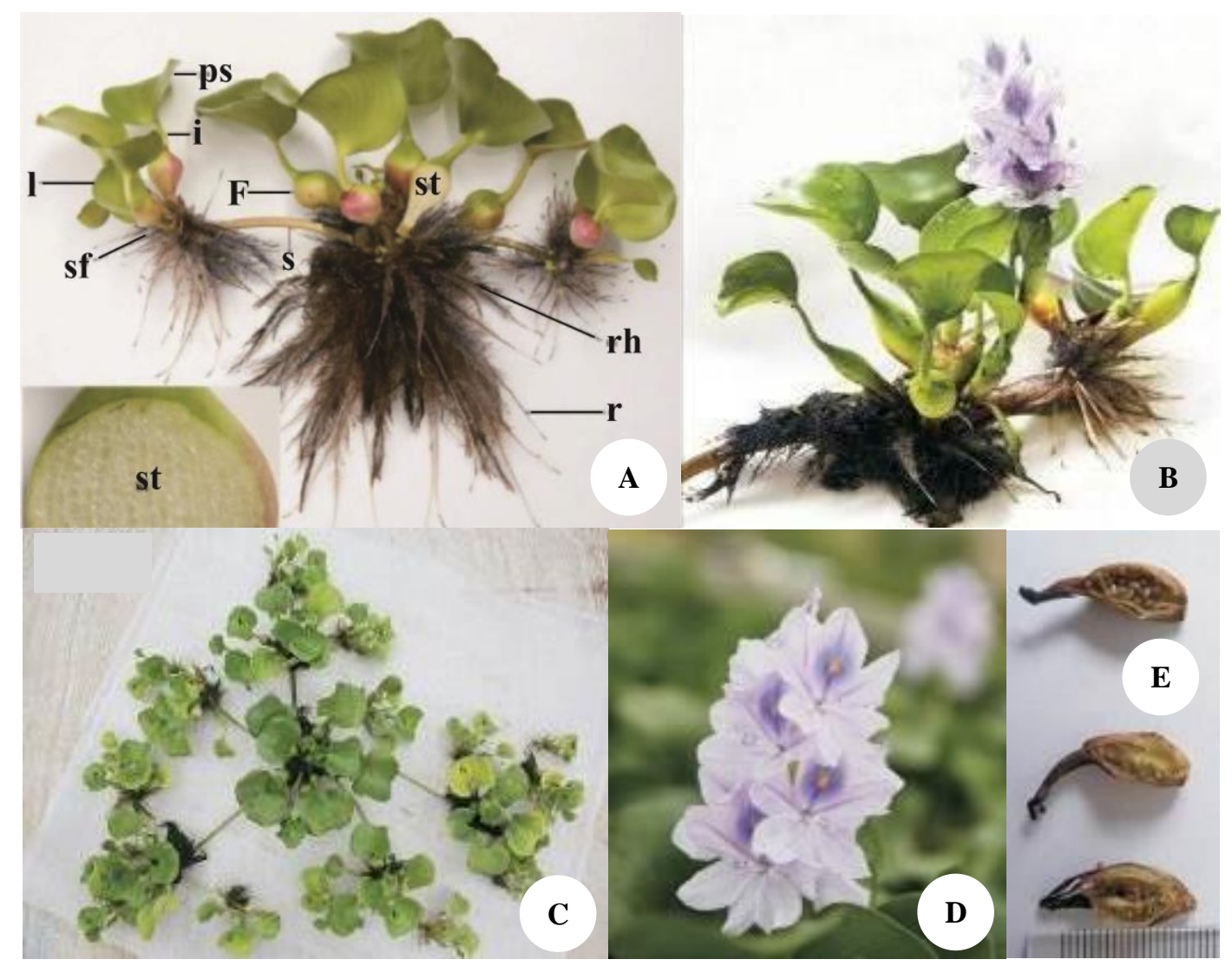

Figure 2. Morphological description of water hyacinth (Eichhornia crassipes). A. Young water hyacinth. 1: ligule; sf: sub float; s: stolon; ps: pseudo-lamina; i: isthmus; f: float; rh: rhizome; r: root; st: sponge tissue. B. Mature water hyacinth, C. Vegetative reproduction, D. Water hyacinth in flower, E. Dehiscent capsules contain 63-153 seeds. (A-D. Photo by Lin Shang 2015; E. Photo by Ying-ying Zhang 2010) 
Water hyacinth is also a significant problem that has the potential to reduce the environmental quality of Rawapening Lake, namely lake sedimentation, coverage of the lake surface by water hyacinth weeds, and increase in the volume of waste entering the lake area from several rivers that flow into the Rawapening Lake (Haseena et al. 2017; Salam and Salwan 2017; Ting et al. 2018; Yunindanova et al. 2020). Wind also affects nutrient dynamics in the lake, causing water hyacinth to float to new areas and triggering sediment resuspension that increases nutrient release in the lake (Worqlul et al. 2020).

In just a few decades, the water hyacinth invasion in Rawapening Lake has been severely increasing. In 1994, water hyacinth covered $18.45 \%$ of Rawapening Lake along with Hydrilla verticillata (7.69\%) and Salvinia sp. (15.36\%) (Goltenboth and Timothy 1994). In 2002, water hyacinth coverage in Rawapening Lake had reached 20$30 \%$ of the surface water areas or about $150 \mathrm{Ha}$ (Utomo 2016). Between 2004 and 2005, the coverage of water hyacinth on the surface of Rawapening Lake increased from $60 \%$ to $70 \%$, then increased again to $85 \%$ in 2006 due to the rapid growth rate of water hyacinth reaching $7.1 \%$ per year (Soeprobowati 2012).
In 2013, water hyacinth invasion reached $45 \%$ of the surface area of Rawapening Lake. This is caused by the water hyacinth growth rate being so fast, where the water hyacinth stems can produce new plants covering an area of $1 \mathrm{~m}^{2}$ within 52 days (Utomo 2016). According to Hidayati et al. (2018), the area of water hyacinth in Rawapening Lake in 2012 was 775.49 ha, while in 2016, it increased to 990.53 ha. According to Soeprobowati (2017), one water hyacinth plant can reproduce and cover an area of water in Rawapening Lake, reaching an area of $1 \mathrm{~m}^{2}$ within 22 days. Based on the research conducted by Prasetyo et al. (2021), the growth rate of water hyacinth must be considered so that the management of Rawapening Lake can be successful. The Relative Growth Rate (RGR) of water hyacinth in Rawapening Lake ranged from 6.40$7.26 \% /$ day. Meanwhile, water hyacinth propagation time (DT) ranged from 9.6-10.8 days. Then, $1 \mathrm{~m}^{2}$ will be full of water hyacinth within 21 days to 28 days. The water hyacinth invasion in Rawapening Lake from year to year is getting out of control because water hyacinth is increasingly covering the lake area (Figure 3).

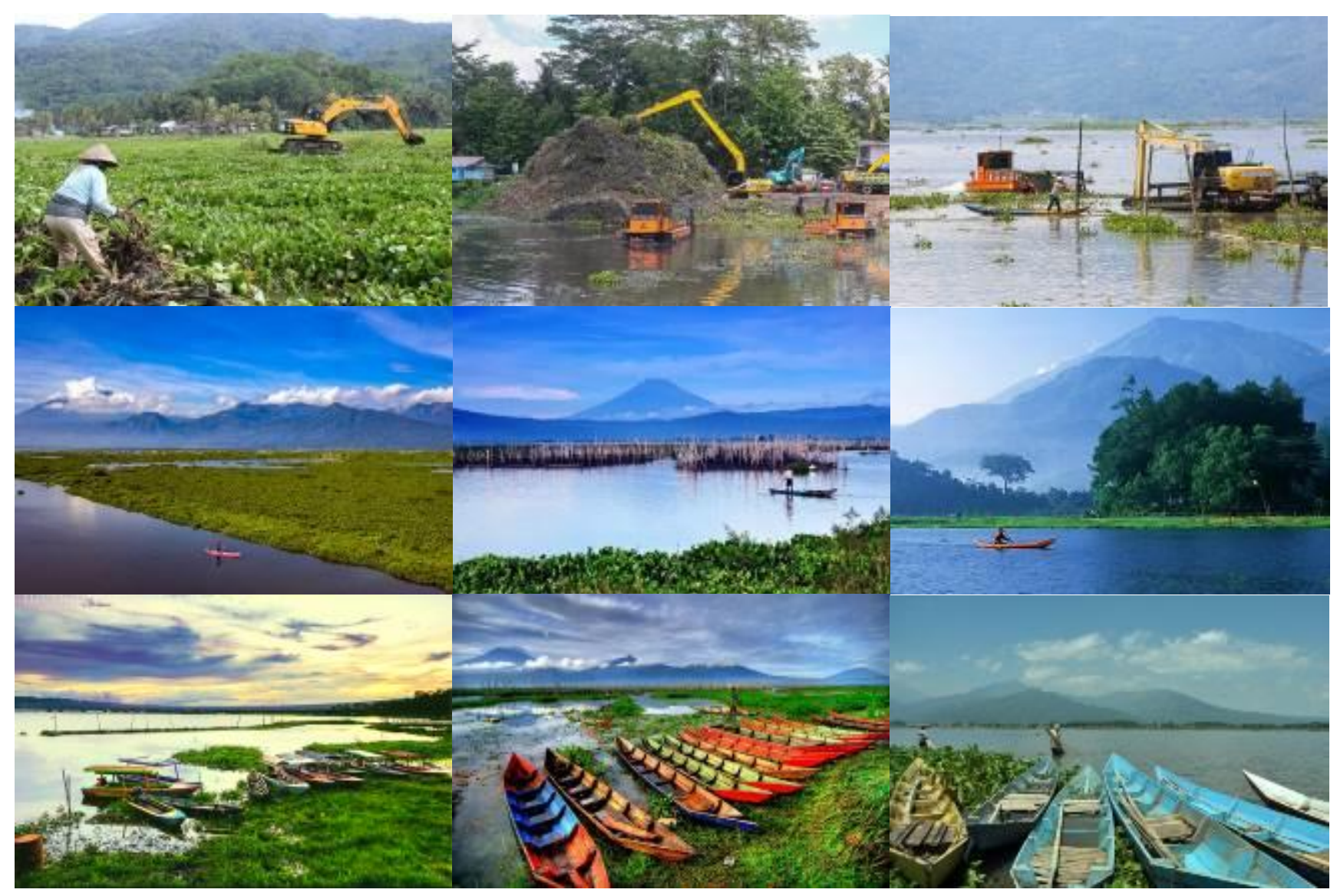

Figure 3. Condition of water hyacinth in Rawapening Lake in 2021 suggests that water hyacinth is everywhere in the lake 
The uncontrollable water hyacinth invasion in Rawapening Lake can cause various negative impacts that affect the surrounding communities' social and economic aspects. The decrease in soluble oxygen in the water because water hyacinth blocks sunlight from entering the water causes a balance disorder in the Rawapening Lake aquatic ecosystem, leading to the decrease in fish production, the loss of endemic organisms, disturbance in irrigation, reduction in the beauty of the waters because the fallen roots will float and cause the water to look very dirty or cloudy, and others (Bornette and Puijalon 2011; Güereña et al. 2015; Kamau et al. 2015; Gupta and Yadav 2020).

The main factor that triggers the rapid growth of water hyacinth in Rawapening Lake is eutrophication due to the increase in the waters' nutrient content, especially phosphorus $(\mathrm{P})$ and nitrogen $(\mathrm{N})$. In addition, temperature and carbonate also significantly affect the growth of water hyacinth (Soeprobowati et al. 2016). Soeprobowati et al. (2012) stated that the eutrophic condition of Rawapening Lake has occurred since 1967, and it is tough to control the growth of water hyacinth because of its fast growth rate and ability to store seeds scattered by flooding (Júnior and Carvalho 2019). Water hyacinths also have seeds that have a dormancy up to 15 years, implying that the seeds have long-lasting regeneration ability (Ojo et al., 2019).

To eradicate the invasion of water hyacinth, biological control is most effective but can take several years to be successful (Van Wilgen and de Lange 2011; Fraser et al. 2016; Su et al. 2018). This involves using natural enemies, including plant pathogens (Dagno et al., 2012). There are several native enemies of water hyacinth, including two South American beetles (Neochetina eichhorniae and Neochetina bruchi) and two species of water hyacinth moth (Niphograpta albiguttalis and Xubida infusella) which have been effective in controlling water hyacinth populations in many countries, especially in Lake Chivero (Zimbabwe), Lake Victoria (Kenya), Louisiana (USA), Mexico, Papua New Guinea, and Benin (Williams et al. 2007; Venter et al. 2012; Gichuki et al. 2012; Dagno et al. 2012).

\section{NEGATIVE ECONOMIC IMPACTS OF WATER HYACINTH IN RAWAPENING LAKE}

The rapid growth and spread of water hyacinth in Rawapening Lake cause detrimental impacts to the economic conditions of the people around the lake, especially the farmers and fishers. In the agricultural sector, water hyacinth is a pest that disturbs agricultural crops. The bush from the water hyacinth plant becomes a nest for rats, which in the event of high tide, the bush pulls over to the agricultural land then eats up the agricultural crops (Ningsih et al. 2019). The spread of water hyacinth into drainages and sewages may cause clogging. The rotten water hyacinth plants can obstruct the irrigation channels of the fields so that farmers cannot produce maximum rice harvests (Chowdhury 2013; Kriticos and Brunel 2016). Water hyacinth that is not controlled will invade agricultural land and livestock grazing, making fodder plants and grasses lose their place of growth.
Unfortunately, water hyacinth cannot be used as animal feed because it contains too much silica, calcium oxalate, potassium, and too little protein (Osumo 2001).

In the health sector, the overgrown water hyacinth provides an ideal habitat for disease carriers such as mosquitoes that cause malaria, inflicting the cost of health treatment when the surrounding community suffering the disease (Minakawa et al. 2012; Njuru et al. 2012; Honlah et al. 2019). In addition, certain bacteria can thrive in water hyacinth habitats. If left unchecked, this will have the opportunity to cause disease outbreaks for humans.

In fisheries sector, water hyacinths that covered the surface water of Rawapening Lake obstruct the activities of fishermen because water hyacinth makes it difficult and hinders the speed of the fishing boats, and disturbs fishermen when casting nets into the lake to look for fish (Ndimele et al. 2011; Patel 2012; Aloo et al. 2013). The large coverage of water hyacinths reduces the soluble oxygen in the water, causing aquatic organisms, especially fish, to find it difficult to get oxygen and eventually die, so that the fish population decreases and fishermen get only a few fish catches (Downing et al. 2012; Schultz and Dibble 2012; Witte et al. 2012; Degaga 2019). This condition is happening in Rawapening Lake which inflicts loss to the fishermen due to the decrease in fish catches (Genissa et al. 2018).

Economic losses suffered by the stakeholders of Rawapening Lake also come from the financial cost to suppress the growth of water hyacinth weeds. Because, the cost to eradicate and manage water hyacinth is expensive, there is a need for environmentally friendly efforts that incur low costs. If possible, the potentials utilization of water hyacinth can be developed to generate economic benefits.

\section{POSITIVE ECONOMIC IMPACTS OF WATER HYACINTH IN RAWAPENING LAKE}

\section{Bioremediation}

Despite the negatives economic impacts caused by water hyacinth invasion, some economic benefits have also been reported. It has been shown, for example, that water hyacinth is a good biosorbent for heavy metals contamination and it can improve the quality of water around the plant cover (Wang et al. 2012; Moyo et al. 2013; Ammar et al. 2014; Wanyonyi et al. 2014; Matindi et al.2014; Pusphe et al. 2016; Feng et al. 2017; Arenas et al. 2018; Ting et al. 2018; Sayago 2019). The remediated water that is not polluted by heavy metals can be used for various uses, for example for agricultural irrigation, so that in can increase economic income (Akinwade et al. 2013; Matindi et al. 2014; Canazart et al. 2017; Gogoi et al. 2017; Priya et al. 2018; Nash et al. 2019).

\section{Handicrafts}

Various products of handicrafts can be made of water hyacinth to generate economic value (Bruneckiene and Sinkiene 2014; Onyango and Ondeng 2015; Guna et al. 2017; Yan et al. 2017; Mitan 2019; Sianturi et al. 2019). 
Communities around Rawapening Lake use the leaf stalks of water hyacinth to make various creative products that have functional value as well as environmentally friendly (Sudana and Mohamad 2020). Craft products produced by communities and enterprises around Rawapening Lake include bags, sandals, baskets, wallets, and furniture such as chairs and tables (Table 1).

The process of craft production with raw materials originated from water hyacinth begins with the drying of wet water hyacinth plants. In adding to the beauty value and economic value, it can use various methods such as embroidery (Putri and Prasetyaningtyas 2019). In its manufacture, the equipment used in the production of this craft consists of a sickle to take raw materials, a press for leveling the water hyacinth, a knife or scissors, a sewing machine to form and unite the supporting materials (cloth or leather). These art products made from water hyacinth are then can distributed either directly or through online media (with social media) so as to generate a number of profits.

\section{Biogas}

In addition, according to Bote et al. (2019), water hyacinth has a high hemicellulose content compared to other organic components, which will produce carbon dioxide and methane gas as biogas. The principle of making biogas is to use the anaerobic decomposition of organic matter, which is closed from free air to produce gas in the form of methane $\left(\mathrm{CH}_{4}\right)$. Several microorganisms, especially methane-producing bacteria, assist the anaerobic decomposition process. Anaerobic digestion is a process in which microorganisms break down biodegradable materials without oxygen (Yonathan et al. 2012). Manufacturing is done by preparing tools and materials. Tools and materials needed are biogas stove, gas generator, drum/gallon, galvanized pipe, hose. The ingredients are water, water hyacinth, cow dung. The mixture consisted of water hyacinth as a substrate, cow dung as a biostarter, and water as a nutrient.

Making biogas begins with water hyacinth chopped into small pieces measuring less than $1 \mathrm{~cm}$, then water and cow dung are added according to the dilution variable. After the appropriate dilution variable, enter the mixed solution into the biodigester. The following process is to let it sit for a week for gas decomposition. Making biogas begins with water hyacinth chopped into small pieces measuring less than $1 \mathrm{~cm}$, then water and cow dung are added according to the dilution variable. After the appropriate dilution variable, enter the mixed solution into the biodigester. The following process is to let it sit for a week for gas decomposition. Then, the gas produced is accommodated in a drum or gallon reservoir and the gas is flowed through a hose to turn on the stove and an electric generator. If the decay of the water hyacinth is good, the fire and electricity can continue to burn. If the decay of the water hyacinth is good, the fire and electricity can continue to burn.

According to Yonathan et al. (2012) who researched making biogas with water hyacinth with the composition of the ratio of water + cow dung: water hyacinth $(2: 1 ; 2: 1.5$; $2: 2 ; 2: 2.5)$. The amount of substrate for each variable in a row are: $326.5 \mathrm{gr}$; $420 \mathrm{gr}$; $490 \mathrm{gr}$; and $543.2 \mathrm{gr}$. The amount of volume produced has increased from variable 2: 1 to variable 2: 2.5 . The results obtained on the composition variable show the largest biogas production at 2:2.5 composition of $1162.97 \mathrm{~mL}$ and the smallest biogas production at $2: 1$ at $12.85 \mathrm{~mL}$. The more the composition of the substrate, the higher the volume of biogas produced. From the results of the Gas Chromatography analysis, it was obtained, and after calculating the methane content formed was $0.03 \mathrm{~mol}$ of methane / 100gr of water hyacinth. From the results of this analysis, it can be concluded that biogas from water hyacinth can be used as a renewable energy source because it is proven that there is methane content in the biogas produced. However, from the results of this study, further research is still needed whether with the longer fermentation time and variations of other variables the methane gas content can still increase or not.

Biogas from water hyacinth is an environmentally friendly material at an affordable price. In that case, when we take advantage of the water hyacinth plants in Lake Rawapening, we can reduce the excessive water hyacinth population. Furthermore, utilizing water hyacinth as an ingredient for biogas is also very helpful for residents who have difficulty obtaining gas and electricity for their daily activities.

\section{Organic fertilizer}

Water hyacinth can also be processed into organic fertilizers that are marketable and also at the same time can reduce its population in Rawapening Lake (Fan et al. 2015; Yunindanova et al. 2020). In the community service activities carried out by Yunindanova et al. (2020) in the Rawapening Lake area and Kadirejo Village, Pabelan Subdistrict, Semarang District, Central Java Province, they studied the practice of making compost using water hyacinth as the main raw material through the aerobic composting method. The fertilizer was made within one until two weeks with nutritional quality that meets the standards of organic fertilizers. The organic fertilizer produced from water hyacinth contains $18.93 \%$ C-organic, $1.78 \%$ total $\mathrm{N}, 1.10 \% \mathrm{P}$, and $1.26 \% \mathrm{~K}$. The production of this fertilizer can generate profits from trade which can be trade enhanced by good packaging and with nutrient analysis (Sudhakar et al. 2013; Hernández-Shek et al. 2916; Goswami et al. 2017). 
Table 1. Various handicraft products with raw materials originated from water hyacinth

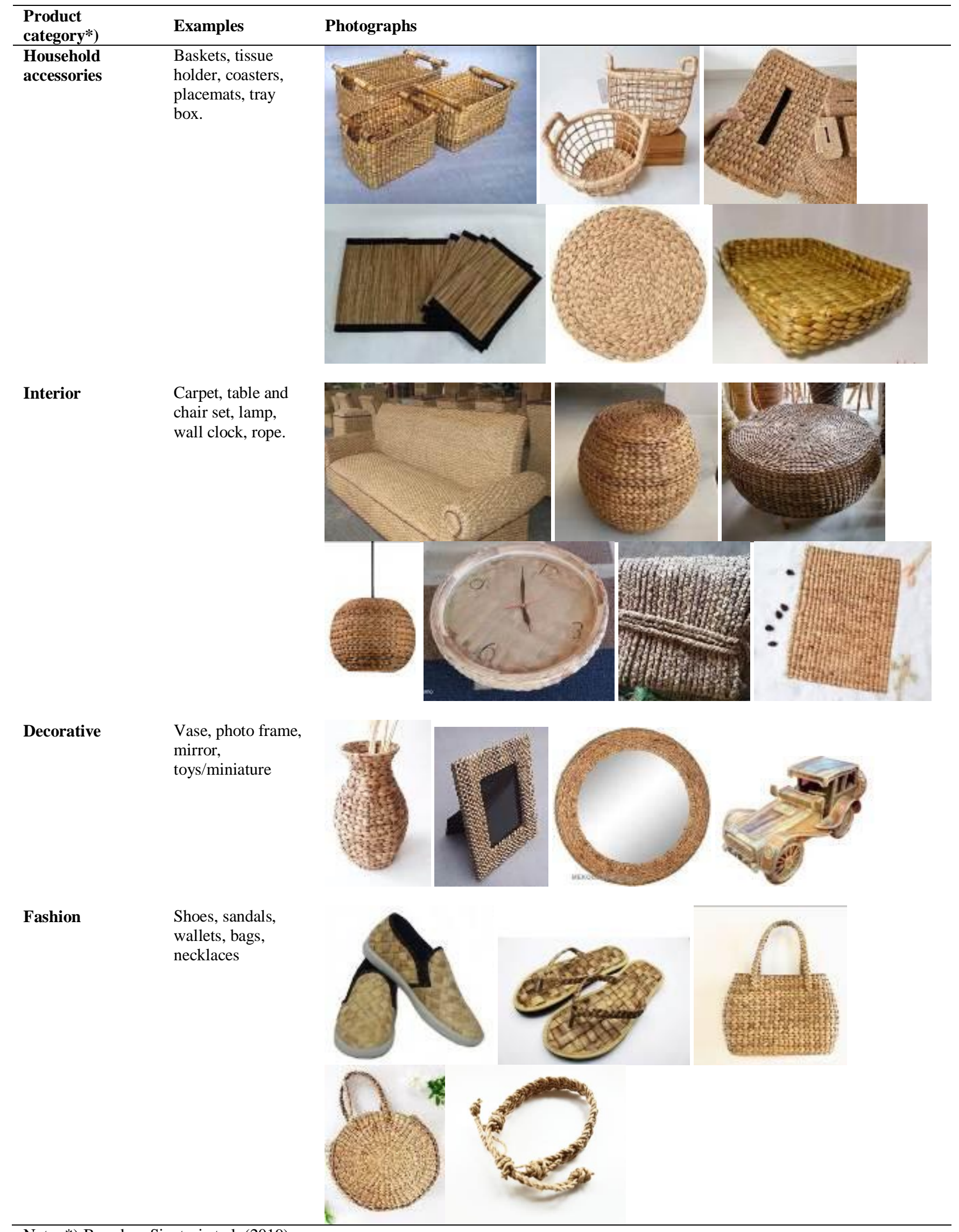




\section{CHALLENGES ON THE UTILIZATION OF WATER HYACINTH IN GENERATING ECONOMIC IMPACTS}

Alternative management of water hyacinth into goods that can be used as appropriate items is a good step to reduce water hyacinth populations and improve water quality. Making water hyacinth-based products can also be an opportunity for improving the community's economy. With the community around the Rawapening Lake area taking part in the production of making water hyacinth goods, this means that these people also have the right to benefit from the distribution of this water hyacinth processed product. Making handicrafts and organic fertilizer from water hyacinth is the best thing for the people around Rawapening Lake because of the cost of making it is relatively easy and does not require expensive technology.

However, there is a challenge in using water hyacinth to reduce/eliminate water hyacinth populations in Lake Rawapening while generating economic benefits. These challenges are: (i) lack of community resources because not all people can make various handicraft products whose raw materials come from water hyacinth, (ii) lack of interest in learning from the younger generation in utilizing water hyacinth so that utilization is not optimal and lacks innovation from products made from water hyacinth produced, (iii) the difficulty of constructing a series of biogas plants and the lack of research on effective biogas production and (iv) not yet comprehensive support provided by the Indonesian government in helping the community to make various handicraft products and fertilizers or other things whose raw materials come from water hyacinth.

Therefore, it is necessary to have a good relationship in establishing cooperation to reduce/eliminate the water hyacinth population in Lake Rawapening while generating economic benefits between the community and the Indonesian government so that human resources are more skilled, there is an increase in the quantity and quality of products, as well as promotion or marketing good product and reach every area.

\section{ACKNOWLEDGEMENTS}

The authors would like to thank some constructive suggestions from reviewers. We also thanks friends and colleagues for their support and advice.

\section{REFERENCES}

Akinwade VO, Mako AA, Babayemii O. 2013. Biomass yield, chemical composition and the feed potential of Water hyacinth (Eichhornia crassipes, Mart. Solms-Laubach) in Nigeria. Int J Agric Sci 3 (8): 659-666.

Aloo P, Ojwang W, Omondi R, Njiru JM, Oyugi D. 2013. A review of the impacts of invasive aquatic weeds on the biodiversity of some tropical water bodies with special reference to Lake Victoria (Kenya). Biodiversity 4 (4): 471-482.
Ammar NS, Elhaes H, Ibrahim HS, Ibrahim MA. 2014. A novel structure for removal of pollutants from wastewater. Spectrochim Acta A Mol Biomol Spectrosc 121: 216-223. DOI: 10.1016/j.saa.2013.10.063.

Arenas OR, Montes AC, Tapia AR, Hernández AT, Cortés GL, Barros OAVE. 2018. Evaluation of aquatic lily (Eichhornia crassipes) and agricultural wastes for production of oyster mushroom. Trop Subtrop Agroecosyst 21 (2): 317 - 327.

Arham I. 2013. Water Hyacinth Control at Various Levels of Growing Media Salinity. [Dissertation]. Universitas Hasanudin, Makassar. [Indonesian]

Arp RS, Fraser GCG, Hill MP. 2017. Quantifying the economic ater savings benefit of water hyacinth (Eichhornia crassipes) control in the Vaalharts Irrigation Scheme. Water SA 43 (1): 58-66. DOI: 10.4314/wsa.v43i1.09.

Arthaud F, Vallod D, Robin J, Bornette G. 2012. Eutrophication and drought disturbance shape functional diversity and life-history traits of aquatic plants in Shallow Lakes. Aquat Sci 74 (3): 471 -481. DOI: 10.1007/s00027-011-0241-4.

Bacher S, Blackburn TM, Essl F, Genovesi P, Heikkilä J, Jeschke JM, Jones G, Keller R, Kenis M, Kueffer C, Martinou AF, Nentwig W, Pergl J, Pyšek P, Rabitsch W, Richardson DM, Roy HE, Saul W-C, Scalera R, Vilà M, Wilson JRU, Kumschick S. 2018. Socio-economic impact classification of alien taxa (SEICAT). Methods Ecol Evol 9 (1): 159-168. DOI: 10.1111/2041-210X.12844.

Barrett SCH. 1989. Waterweed invasions. Sci Am 261 (4): 90-97. DOI: 10.1038/scientificamerican0189-90.

Bartz R, Kowarik I. 2019. Assessing the environmental impacts of invasive alien plants: A review of assessment approaches. Neo Biota 43 (1): 69-99. DOI: 10.3897/neobiota.43.30122.

Blackburn TM, Essl F, Evans T, Hulme PE, Jeschke JM, Kühn I, Kumschick S, Markova Z, Mrugala A, Nentwig W, Pergl J, Pyšek P, Rabitsch W, Ricciardi A, Richardson DM, Sendek A, Vilà M, Wilson JRU, Winter M, Genovesi P, Bacher S. 2014. A unified classification of alien species based on the magnitude of their environmental impacts. PLoS Biol 12 (5): e1001850. DOI: 10.1371/journal.pbio.1001850.

Booy O, Cornwall L, Parrott D, Sutton-Croft M, Williams F. 2017. Impact of biological invasins on infrastructure. In: Vilà M, Hulme PE (eds) Impact of Biological Invasions on Ecosystem Services. Springer International, Cham. DOI: 10.1007/978-3-319-45121-3_15.

Bornette G, Puijalon S. 2011. Response of aquatic plants to abiotic factors: A review. Aquat Sci 73 (1): 1-14. DOI: 10.1007/s00027-0100162-7.

Bote MA, Naik VR, Jagdeeshgouda KB. 2019. Production of biogas with aquatic weed water hyacinth and development of briquette making machine. Mater Sci Energy Technol 3: 64-71. DOI: 10.1016/j.mset.2019.09.001.

Bruneckiene J, Sinkiene J. 2014. Critical Analysis of Approaches to Smart Economy. The 8th International Scientific Conference Business and Management, Smart Development, Vilnius, Lithuania. DOI: 10.3846/bm.2014.106.

Buerger A, Howe K, Jacquart E, Chandler M, Culley T, Evans C, Kearns K, Schutzki R, Van Riper L. 2016. Risk assessments for invasive plants: A Midwestern U.S. comparison. Invasive Plant Sci Manag 9 (1): 41-54. DOI: 10.1614/IPSM-D-15-00018.1.

Canazart DA, Nunes AR da C, Sanches M, Conte H. 2017. Phytoremediation agro-industrial wastewater of using macrophyte Eichhornia crassipes. Braz J Surg Clin Res BJSCR 17: 87-91.

Caplat P, Coutts SR. 2011. Integrating ecological knowledge, public perception and urgency of action into invasive species management. Environ Manag 48: 878-881. DOI: 10.1007/s00267-011-9747-8.

Chislock MF, Doster E, Zitomer RA, Wilson AE. 2013 Eutrophication: Causes, consequences, and controls in aquatic ecosystems. Nat Educ Knowl 4 (4): 10.

Chowdhury NT. 2013. Marginal product of irrigation expenses in Bangladesh. Water Resour Econ 4: 38-51. DOI: 10.1016/j.wre.2013.11.002.

Chunkao K, Nimpee C, Duangmal. 2012. The King's initiatives using Water hyacinth to remove heavy metals and plant nutrients from wastewater through Bueng Makkasan in Bangkok, Thailand. Ecol Eng 39: 40-52. DOI: 10.1016/j.ecoleng.2011.09.006.

Clout MN, Williams PA. 2009. A Handbook of Principles and Techniques: Invasive Species Management. Oxford University Press, United States. 
Coetzee JA, Hill MP. 2012. The role of eutrophication in the biological control of Water hyacinth, Eichhornia crassipes, in South Africa. BioControl 57 (2): 247-261. DOI: 10.1007/s10526-011-9426-y.

Coetzee JA, Hill MP, Byrne MJ, Bownes A. 2011. A review of the biological control programmes on Eichhornia crassipes (C. Mart.) Solms (Pontederiacaeae), Salvinia molesta D.S. Mitch. (Salviniaceae), Pistia stratiotes L. (Araceae), Myriophyllum aquaticum (Vell.) Verdc. (Haloragaceae) and Azolla filiculoides Lam. (Azollaceae) in South Africa. Afr Entomol 19 (1): 451-468. DOI: 10.4001/003.019.0202.

Coetzee JA, Jones RW, Hill MP. 2014. Water hyacinth, Eichhornia crassipes (Pontederiaceae), reduces benthic macroinvertebrate diversity in a protected subtropical lake in South Africa. Biodiv Conserv 23 (5): 1319-1330. DOI: 10.1007/s10531-014-0667-9.

Courchamp F, Fournier A, Bellard C, Bertelsmeier C, Bonnaud E, Jeschke JM, Russel JC. 2017. Invasion biology: Specific problems and possible solutions. Trends Ecol Evol 32 (1): 13-22. DOI: 10.1016/j.tree.2016.11.001

Dagno K, Lahlali R, Diourte M, Haissam J. 2012. Fungi occurring on Water hyacinth (Eichhornia crassipes [Martius] Solms-Laubach) in Niger River in Mali and their evaluation as Mycoherbicides. J Aquat Plant Manag 50: 25-32.

Dana ED, Jeschke JM, Garcia-de-Lomas J. 2014. Decision tools for managing biological invasions: Existing biases and future needs. Oryx 48 (1): 56-63. DOI: 10.1017/ S0030605312001263.

David P, Thebault E, Anneville O, Duyck PF, Chapuis E, Loeuille N. 2017. Impacts of invasive species on food webs: A review of empirical data. Networks of invasion: A synthesis of concepts. Adv Ecol Res 56: 1-60. DOI: 10.1016/bs.aecr.2016.10.001.

Degaga AH. 2019. Water hyacinth (Eichhornia crassipes) Biology and its impacts on ecosystem, biodiversity, economy and human well-being. J Nat Sci Res 9 (12): 24-30. DOI: 10.7176/JNSR.

Dereje T, Erkie A, Wondie Z, Brehan M. 2017. Identification of impacts, some biology of Water hyacinth (Eichhornia crassipes) and its management options in Lake Tana, Ethiopia. Net J Agric Sci 5 (1): 8 15. DOI: 10.30918/NJAS.51.16.039.

Downing AS, Van Nes EH, Janse JH, Witte F, Cornelissen IJ, Scheffer M, Mooij WM. 2012. Collapse and reorganization of a food web of Mwanza Gulf, Lake Victoria. Ecol Appl 22 (1): 229-239. DOI: 10.1890/11-0941.1.

Epanchien-Niell RS. 2017. Economics of invasive species policy and management. Biol Invasions 19 (11): 3333-3354. DOI: 10.1007/s10530-017-1406-4.

Essl F, Hulme PE, Jeschke JM, Keller R, Pysek P, Richardson DM, Saul WF, Bacher S, Dullinger S, Esteves RA, Kueffer C, Roy HE, Seeben H, Rabitsch W. 2017. Scientific and normative foundation for the valuation of alie-species impacts: thirteen core principles. BioScience 67 (2):166-178. DOI: 10.1093/biosci/biw160.

Essl F, Nehring S, Klingenstein F, Milasowszky N, Nowack C. 2011. Review of risk assessment systems of IAS in Europe and introducing the German-Austrian Black List Information System (GABLIS). J Nat Conserv 19 (6): 339-350. DOI: 10.1016/j.jnc.2011.08.005.

Fan R, Luo J, Yan S, Wang T, Liu L, Gao Y, Zhang Z. 2015. Use of Water hyacinth (Eichhornia crassipes) compost as a peat substitute in soilless growth media. Compost Sci Util 23 (4): 237-247. DOI: 10.1080/1065657X.2015.1046614

Feng W, Xiao K, Zhou W, Zhu D, Zhou Y, Yuan Y, Xiao N, Wan X, Hua Y, Zhao J. 2017. Analysis of utilization technologies for Eichhornia crassipes biomass harvested after restoration of wastewater. Bioresour Technol 223: 287-295. DOI 10.1016/j.biortech.2016.10.047.

Foxcroft LC, Pyšek P, Richardson DM, Genovesi P, MacFadyen S. 2017. Plant invasion science in protected areas: Progress and priorities. Biol Invasions 19 (5): 1353-1378. DOI: 10.1007/s10530-016-1367-z.

Fraser GCG, Hill MP, Martin JA. 2016. Economic evaluation of water loss saving due to the biological control of Water hyacinth at New Year's Dam, Eastern Cape province, South Africa. Afr J Aquat Sci 41 (2): 227-234. DOI: 10.2989/16085914.2016.1151765.

Frezina NCA. 2013. Assessment and utilization of water hyacinth in the water bodies of Tamil Nadu. IJSRP 2: 58-77.

Gaertner M, Larsona BMH, Irlicha UM, Holmes PM, Stafford L, van Wilgen BW, Richardson DM. 2016. Managing invasive species in cities: A framework from Cape Town, South Africa. Landsc Urban Plan 151: 1-9. DOI: 10.1016/j.landurbplan.2016.03.010
Gaikwad RP, Gavande S. 2017. Major factors contributing growth of Water hyacinth in Natural Water Bodies. Int J Eng Res 6 (6): 304306. DOI: 10.5958/2319-6890.2017.00024.1.

Gallardo B, Clavero M, Sanchez MI, Vila M. 2016. Global ecological impacts of invasive species in aquatic ecosystems. Glob Change Biol 22 (1): $151-163$. DOI: $10.1111 / \mathrm{gcb} .13004$

Genissa N, Boedoyo MS, Yoesgiantoro D. 2018. Analysis of the costs and benefits of Water hyacinth wood pellets as alternative energy to increase energy security. Jurnal Ketahanan Energi 4 (2): 92-114. [Indonesian]

Genovesi P, Carboneras C, Vilà M, Walton P. 2015. EU adopts innovative legislation on invasive species: A step towards a global response to biological invasions? Biol Invasions 17 (5): 1307-1311. DOI: 10.1007/s10530-014-0817-8.

Gichuki J, Omondi R, Boera P, Tom Okorut T, SaidMatano A, Jembe T, Ofulla A. 2012. Water hyacinth Eichhornia crassipes (Mart.) Solmslaubach dynamics and succession in the Nyanza Gulf of Lake Victoria (East Africa): Implications for water quality and biodiversity conservation. Sci World J 2012 (1): 106429. DOI: $10.1100 / 2012 / 106429$.

Gogoi P, Adhikari P, Maji TK. 2017. Bioremediation of arsenic from water with citric acid cross-linked Water hyacinth (E. crassipes) root powder. Environ Monit Assess 189 (8): 1-11. DOI: 10.1007/s10661017-6068-2.

Goltenboth F, Timotius KH. 1994. Rawapening Lake in Central Java, Indonesia. Satya Wacana University Press, Salatiga. [Indonesian]

Gopal B. 1987. Water Hyacinth. Elesevier, New York.

Goswami L, Nath A, Sutradhar S, Bhattacharya SS, Kalamdhad A, Vellingiri K, Kim K-H. 2017. Application of drum compost and vermicompost to improve soil health, growth, and yield parameters for tomato and cabbage plants. J Environ Manag 200: 243-252. DOI: 10.1016/j.jenvman.2017.05.073.

Grasset C, Abril G, Guillard L, Delolme C, Bornette G. 2016. Carbon emission along a eutrophication gradient in temperate riverine wetlands: Effect of primary productivity and plant community composition. Freshw Biol 61 (9): 1405-1420. DOI: 10.1111/fwb.12780.

Güereña D, Neufeldt H, Berazneva J, Dubyd S. 2015. Water hyacinth control in Lake Victoria: Transforming an ecological catastrophe into economic, social, and environmental benefits. Sustain Prod Consum 3: 59-69. DOI: 10.1016/j.spc.2015.06.003.

Guignard MS, Leitch AR, Acquisti C, Eizaguirre C, Elser JJ, Hessen DO, Jeyasingh PD, Neiman M, Richardson AE, Soltis PS, Soltis DE, Stevens CJ, Trimmer M, Weider LJ, Woodward G, Leitch IJ. 2017. Impacts of nitrogen and phosphorus: from genomes to natural ecosystems and agriculture. Front Ecol Evol 5: 70. DOI: 10.3389/fevo.2017.00070

Guna V, Ilangovan M, Anantha Prasad MG, Reddy N. 2017. Water hyacinth: A unique source for sustainable materials and products. ACS Sustain Chem Eng 5 (6): 4478-4490. DOI: 10.1021/acssuschemeng.7b00051.

Gupta AK, Yadav D. 2020. Biological control of Water hyacinth. Environ Contam Rev 3 (1): 37-39.

Hanley N, Robert M. 2019. The economic benefits of invasive species management. People Nat 1 (2): 124-137. DOI: 10.1002/pan3.31.

Haryani GS 2013. Lake conditions in Indonesia and its management strategies. Limnol LIPI 2: 1-19. [Indonesian]

Haseena M, Malik MF, Javed A, Arshad S, Asif N, Zulfiqar S, Hanif J. 2017. Water pollution and human health. Environ Sci 1 (3): 16-19. DOI: $10.4066 / 2529-8046.100020$

Hernández-Shek MA, Cadavid-Rodríguez LS, Bolaños IV, AgudeloHenao AC. 2016. Recovering biomethane and nutrients from anaerobic digestion of Water hyacinth (Eichhornia crassipes) and its co-digestion with fruit and vegetable waste. Water Sci Technol 73 (2): 355-361. DOI: $10.2166 /$ wst.2015.501

Hidayati N, Soeprobowati TR, Helmi M. 2018. The evaluation of Water hyacinth (Eichhornia crassiper) control program in Rawapening Lake, Central Java Indonesia. IOP Conf Ser: Earth Environ Sci 142: 012016. DOI: 10.1088/1755-1315/142/1/012016.

Hoffmann BD, Broadhurst LM. 2016. The economic cost of managing invasive species in Australia. Neobiota 31: 1-18. DOI: 10.3897/neobiota.31.6960.

Honlah E, Segbefia AO, Appiah DO, Mensah M, Atakora PO. 2019. Effects of water hyacinth invasion on the health of the communities, and the education of children along River Tano and Abby- Tano 
Lagoon in Ghana. Cogent Soc Sci 5 (1): 1619652. DOI: 10.1080/23311886.2019.1619652.

Huang J, Zhou K, Zhou, Zhang W, Deng X, van der Werf W, Lu Y, Wu K, Rosegrant MW. 2018. Uncovering the economic value of natura enemies and true cost of chemical insecticides to cotton farmer in China. Environ Res Lett 13 (6): 064027. DOI: 10.1088/17489326/aabfb0.

Hulme PE, Pyšek P, Jarošík V, Pergl J, Schaffner U, Vilà M. 2013. Bias and error in understanding plant invasion impacts. Trends Ecol Evo 28 (4): 212-218. DOI: $10.1016 / j$.tree.2012.10.010.

Ilo OP, Simatele MD, Nkomo SL, Mkhize NM, Prabhu NG. 2020. The benefits of water hyacinth (Eichhornia crassipes) for Southern Africa: A Review. Sustainability 12 (21): 9222. DOI: 10.3390/su12219222.

Jeschke JM, Bacher S, Blackburn TM, Dick JTA, Essl F, Evans T, Gaertner M, Hulme P, Kühn I, Mrugala A, Pergl J, Pyšek P, Rabitsch W, Ricciardi A, Richardson DM, Sendek A, Vilà M, Winter M, Kumschick S. 2014. Defining the impact of non-native species. Conserva Biol 28 (5): 1188-1194. DOI: 10.1111/cobi.12299.

Juma DW, Wang H, Li F. 2014. Impacts of population growth and economic development on water quality of a lake: Case study of Lake Victoria Kenya water. Environ Sci Pollut Res Intl 21 (8): 5737-5746. DOI: $10.1007 / \mathrm{s} 11356-014-2524-5$.

Júnior WRC, Carvalho LBD. 2019. Control of water hyacinth: a shor review. Commun Plant Sci 9: 129-132. DOI: 10.26814/cps2019021.

Kamau AN, Njogu P, Kinyua R, Sessay M. 2015. Sustainability challenges and opportunities of generating biogas from water hyacinth in Ndunga Village, Kenya. ACTS 5: 1-24.

Kapler EJ, Thompson JR, Widrlechner MP. 2012 Assessing stakeholder perspectives on invasive plants to inform risk analysis. Invasive Plant Sci Manag 5 (2): 194-208. DOI: 10.1614/IPSM-D-11-00067.1.

Kowarik I. 2011. Novel urban ecosystems, biodiversity, and conservation. Environ Pollut 159 (8/9): 1974-1983. DOI: 10.1016/j. envpol.2011.02.022.

Knoll LB, Vanni J, Renwick WN. 2003. Phytoplankton primary production and photosynthesis parameters in reservoir along gradient of watershed land-use. Limnol Oceanogr 48 (2): 608-617. DOI: $10.4319 /$ lo.2003.48.2.0608

Kriticos DJ, Brunel S. 2016. Assessing and managing the current and future pest risk from water hyacinth (Eichhornia crassipes) an invasive aquatic plant threatening the environment and water security PLoS One 11 (8): e0120054. DOI: 10.1371/ journal.pone.0120054.

Kumschick S, Bacher S, Dawson W, Heikkilä J, Sendek A, Pluess T, Robinson TB, Kühn I. 2012. A conceptual framework for prioritization of IAS for management according to their impact. NeoBiota 15: 69-100. DOI: 10.3897/neobiota.15.3323.

Kumschick S, Gaertner M, Montserrat V, Essl F, Jeschke JM, Pyšek P, Ricciardi A, Bacher S, Blackburn T, Dick JTA, Evans T, Hulme PE, Kühn I, Mrugala A, Pergl J, Rabitsch W, Richardson DM, Sendek A, Winter M. 2015. Ecological impacts of alien species: quantification, scope, caveats, and recommendations. BioScience 65 (1): 55-63. DOI 10.1093/biosci/biu193.

Kumschick S, Richardson DM. 2013. Species-based risk assessments for biological invasions: advances and challenges. Divers Distrib 19 (9): 1095-1105. DOI: $10.1111 /$ ddi.12110.

Lestari AA, Muslimin MB, Rosmiati R, Mahi F. 2018. Training utilization of hyacinth weeds as alternative fertilizer. J Character Educ Soc 1 (2): 24-29. DOI: $10.31764 /$ jces.v1i2.1526

Leung B, Roura-Pascual N, Bacher S, Heikkilä J, Brotons L, Burgman MA, Dehnen-Schmutz K, Essl F, Hulme PE, Richardson DM, Sol D, Vilà M. 2012. TEASIng apart alien species risk assessments: A framework for best practices. Ecol Lett 15 (12): 1475-1493. DOI 10.1111/ele.12003

Llewelyn J, Phillips BL, Brown GP, et al. 2011. Adaptation or preadaptation: why are keelback snakes (Tropidonophis mairii) less vulnerable to invasive cane toads (Bufo marinus) than are other Australian snakes? Evol Ecol 25 (1): 13-24. DOI: 10.1007/s10682010-9369-2.

Lodge DM, Deines A, Gherardi F, Yeo DCT, Arcella T, Baldridge AK, Barnes MA, Chadderton WL, Feder JL, Gantz CA, Howard GW Jerde CL, Peters BW, Peters JA, Sargent LW, Turner CR, Wittmann ME, Zeng Y. 2012. Global introduction of crayfishes: Evaluating the impact of spesies invasion on ecosystem services. Annu Rev Ecol Evol Syst 43: 449-472. DOI: 10.1146/annurev-ecolsys-111511103919.

Madian HR, Sidkey NM, Elsoud MMA, Hamouda HI, Elazzazy AM. 2019. Bioethanol production from Water hyacinth hydrolysate by
Candida tropicalis Y-26. Arab J Sci Eng 44: 33-41. DOI: 10.1007/s13369-018-3247-6.

Masifwa WF, Twongo T, Denny P. 2001. The impact of water hyacinth, Eichhornia crassipes (Mart) Solms on the abundance and diversity of aquatic macroinvertebrates along the shores of northern Lake Victoria, Uganda. Hydrobiologia 452 (1): 79-88. DOI: 10.1023/A: 1011923926911

Mathur P, Mathur SM. 2017. Water Hyacinth: A Useful Plant to Improve Rural Economy. Water Science and Technology Library. Springer, Singapore. DOI: 10.1007/978-981-10-5798-4_3

Matindi CN, Njogu P, Kinyua R, Nemoto Y. 2014, Analysis of heavy metal content in Water hyacinth (Eichhornia crassipes) from Lake Victoria, Kenya. Proceedings of Sustainable Research and Innovation Conference. Nairobi, Kenya 7-9 May 2014.

McConnachie MM, Cowling RM, van Wilgen BW, McConnachie DA. 2012. Evaluating the cost-effectiveness of invasive alien plant clearing: A case study from South Africa. Biol Conserv 155: 128-135. DOI: 10.1016/j.biocon.2012.06.006.

Minakawa N, Dida GO, Sonye GO, Futami K, Njenga SM. 2012. Malaria vectors in Lake Victoria and adjacent habitats in western Kenya. PLoS ONE 7 (3): e32725. DOI: 10.1371/journal.pone.0032725.

Mironga JM, Mathooko JM, Onywere SM. 2011. The effect of Water hyacinth (Eichhornia crassipes) infestation on phytoplankton productivity in Lake Naivasha and the status of control. J Environ Sci Eng 5 (10): 1252-1261.

Mitan NMM. 2019. Water hyacinth: potential and threat. Mater Today Proc 19: 1408-1412. DOI: 10.1016/j.matpr.2019.11.160.

Mkumbo O, Marshall B. 2014. The Nile perch fishery of Lake Victoria: Current status and management challenges. Fish Manag Ecol 22 (1): 56-63. DOI: $10.1111 /$ fme.12084.

Mostert E, Gaertner M, Holmes PM, Rebelo AG, Richardson DM. 2013. Impact of invasive alien trees on threatened lowland vegetation types in the Cape Floristic Region, South Africa. S Afr J Bot 108: 209-222. DOI: 10.1016/j.sajb.2016.10.014.

Moyo P, Chapungu L, Mudzengi B. 2013. Effectiveness of water hyacinth (Eichhornia crassipes) in remediating polluted water: The case of Shagase river in Masvingo, Zimbabwe. Adv Appl Sci Res 4: 55-62.

Nash DAH, Abdullah SRS, Hassan HA, Idris M, Muhammad NF, Albaldwi IA, Ismail NI. 2019. Phytoremediation of nutrients and organic carbon from sago mill effluent using Water hyacinth (Eichhornia crassipes). J Eng Technol Sci 51 (4): 573-584. DOI: 10.5614/j.eng.technol.sci.2019.51.4.8.

Ndimele P, Kumolu-Johnson C, Anetekhai M. 2011. The invasive aquatic macrophyte, water hyacinth (Eichhornia crassipes (Mart.)) SolmLaubach: Pontedericeae\}: Problems and prospects. Res J Environ Sci 5 (6): 509-520. DOI: 10.3923/rjes.2011.509.520.

Ningsih YW, Kurniawan T, Rahmawati AN, Permatasari DA, Ghunarso DAH, Pratama RA, Sanjaya AM, Widiyatmoko W. 2019. Public perception of the Rawapening Lake Water hyacinth plant in Banyubiru Village, Semarang Regency. Jurnal Geografi, Edukasi dan Lingkungan 3 (2): 83-91. DOI: 10.29405/jgel.v3i2.3488. [Indonesian]

Njuru M, Othina A, Wakwabi E. 2012, Impact of water hyacinth, Eichhornia crassipes (Mart.) Solms-Laubach, on the fishery of Lake Victoria, Kenya.

Ojo EO, Okwu M, Otu LE, Ayawale FA. 2019. Initial assessment of reuse of sustainable wastes for fibreboard production: Yhe case of waste paper and Water hyacinth. J Mater Cycles Waste Manag 22 (6): 222231. DOI: 10.1007/s10163-019-00871-z.

Onyango JP, Ondeng MA. 2015. The contribution of the multiple usage of Water hyacinth on the economic development of reparian communities in Dunga and Kichinjio of Kisumu Central Sub County, Kenya. Am J Renew Sustain Energy 1 (3): 128-132.

Osumo MW. 2001. Effects of Water Hyacinth on Water Quality of Winam Gulf, Lake Victoria. UNU-Fisheries Training Programme, Skulagata, Iceland.

Patel S. 2012. Threats, management and envisaged utilizations of aquatic weed Eichhornia crassipes: An overview. Rev Environ Sci Biotechnol 11 (3): 249-259. DOI: 10.1007/s11157-012-9289-4.

Pejchar L, Mooney HA. 2009. Invasive species, ecosystem services and human well-being. Trends Ecol Evol 24 (9): 497-504. DOI: 10.1016/j.tree.2009.03.016.

Prasetyo S, Anggoro, Soeprobowati TR. 2021. The growth rate of Water hyacinth (Eichhornia crassipes (Mart.) Solms) in Rawapening Lake, Central Java. J Ecol Eng 22 (6): 222-231. DOI: 10.12911/22998993/137678. 
Presidential Regulation No. 18, Year 2020, Concering The National Medium-Term Development Plan 2020-2024. [Indonesian]

Priya P, Nikhitha SO, Anand C, Nath RSD, Krishnakumar B. 2016. Biomethanation of water hyacinth biomass. Bioresour Technol 255: 288-292. DOI: 10.1016/j.biortech.2018.01.119.

Pushpa TB, Vijayaraghavan J, Vijayaraghavan K, Jegan J. 2016 Utilization of effective microorganisms-based water hyacinth compost as biosorbent for the removal of basic dyes. Desalin Water Treat 57 (51): 24368-24377. DOI: 10.1080/19443994.2016.1143405.

Putri D, Prasetyaningtyas W. 2019. Feasibility study of water hyacinth laptop bag with ribbon embroidery decoration. Teknobuga 7 (2): 119 125. [Indonesian]

Pyšek P, Jarošík V, Hulme PE, Pergl J, Hejda M, Schaffner U, Vilà M. 2012. A global assessment of alien invasive plant impacts on resident species, communities and ecosystems: The interaction of impact measures, invading species traits and environment. Glob Change Biol 18: 1725-1737. DOI: 10.1111/j.1365-2486.2011.02636.x.

Rakotoarisoa TF, Waeber PO, Richter T, Mantilla Contreras IJ. 2015. Water hyacinth (Eichhornia crassipes) any opportunities for the Alaotra wetlands and livelihoods. MCD 10 (3): 128-136. DOI 10.4314/mcd.v10i3.5.

Ratnani RD. 2012. The ability of the combination of water hyacinth and activated sludge to reduce pollution in the liquid waste of the tofu industry. Jurnal Majalah Ilmiah Momentum 8 (1): 1-5. [Indonesian]

Ricciardi A, Hoopes MF, Marchetti MP, Lockwood JL. 2013. Progress toward understanding the ecological impacts of non-native species. Ecol Monogr 83 (3): 263-282. DOI: 10.1890/13-0183.1.

Riley CB, Herms DA, Gardiner MM. 2018. Exotic trees contribute to urban forest diversity and ecosystem services in inner-city Cleveland, OH. Urban For Urban Green 29: 367-376. DOI 10.1016/j.ufug.2017.01.004.

Roy HE, Rabitsch W, Scalera R, Stewart A, Gallardo B, Genovesi P, Essl F, Adriaens T, Bacher S, Booy O, Branquart E, Brunel S, Copp GH, Dean H, D'hondt B, Josefsson M, Kenis M, Kettunen M, Linnamag M, Lucy F, Martinou A, Moore N, Nentwig W, Nieto A, Pergl J, Peyton J, Roques A, Schindler S, Schönrogge K, Solarz W, Stebbing PD, Trichkova T, Vanderhoeven S, van Valkenburg J, Zenetos A 2018. Developing a framework of minimum standards for the risk assessment of alien species. J Appl Ecol 55 (2): 526-538. DOI: 10.1111/1365-2664.13025.

Russel JC, Meye JY, Holmes ND, Pagad S. 2017. Invasive alien species on island: impacts, distribution, interaction and management. Environ Conserv 44 (4): 359-370. DOI: 10.1017/S0376892917000297.

Salam H, Salwan A. 2017. Water quality assessment of Al-Gharaf river, south of Iraq using multivariate statistical techniques. ANJS 20 (2): 114-122. DOI: $10.22401 /$ JNUS.20.2.16

Sayago UFC. 2019. Design of a sustainable development process between phytoremediation and production of bioethanol with Eichhornia crassipes. Environ Monit Assess 191 (4): 1-8. DOI: 10.1007/s10661 019-7328-0.

Schirmel J, Bundschuh M, Entling MH, Kowarik I, Buchholz S. 2016 Impacts of invasive plants on resident animals across ecosystems taxa, and feeding types: A global assessment. Glob Change Biol 22 (2): 594-603. DOI: $10.1111 / \mathrm{gcb} .13093$.

Schlaepfer M, Sax DF, Olden JD. 2011. The potential conservation value of non-native species. Conserv Biol 25 (30: 428-437. DOI: 10.1111/j.1523-1739.2010.01646.x

Schultz R, Dibble E. 2012. Effects of invasive macrophytes on freshwater fish and macroinvertebrate communities: The role of invasive plant traits. Hydrobiologia 684 (1): 1-14. DOI: 10.1007/s10750-011-0978-

Sharma A, Aggarwal NK, Saini A, Yadav A, 2016. Beyond biocontrol: water hyacinth-opportunities and challenges. J Environ Sci Technol 9 (1): 26-48. DOI: 10.3923/jest.2016.26.48.

Sianturi OO, Tyas WP, Sunarti, Manullang OR, Manaf A .2019. The Benefit of internet using to affect income for Water Hyacinth homebased entrepreneurs in Rawapening Lake Area-Indonesia. IOP Conf Ser: Earth Environ Sci 248: 012004. DOI: 10.1088/17551315/248/1/012004.

Simberloff D. 2011. Non-natives: 141 scientists object. Nature 475: 36 DOI: $10.1038 / 475036$.

Soeprobowati TR, Hadisusanto S, Gell P. 2012. The diatom stratigraphy of Rawapening Lake, implying eutrophication history. Am J Environ Sci 8 (3): 334-344. DOI: 10.3844/Ajessp.2012.334.344

Soeprobowati TR, Tandjung SD, Sutikno, Hadisusanto S, Gell P, Hadiyanto, Suedy AWA. 2016. The water quality parameters controlling diatoms assemblage in Rawapening Lake, Indonesia. Biodiversitas 17 (2): 657-664. DOI: 10.13057/biodiv/d170239.

Soeprobowati TR. 2017. Lake management: lesson learn from Rawapening Lake. J Comput Theor Nanosci 23 (7): 6495-6497. DOI: 10.1166/asl.2017.9664.

Soeprobowati TS. 2012. Mitigation of eutrophic lake: A case study of Rawapening Lake. Proceedings of the VI National Seminar on Limnology 4: 36-48. [Indonesian]

Solfiyeni S, Chairul C, Marpaung M. 2016. Analysis of invasive plant vegetation in the Lembah Anai Nature Reserve, West Sumatra. Proc Biol Educ Conf: Biol Sci Environ Learn 13 (1): 743-747.

Sood A, Uniyal PL, Prasanna R, Ahluwalia AS. 2012. Phytoremediation potential of aquatic macrophyte, Azolla. Ambio 41 (2): 122-137. DOI: $10.1007 / \mathrm{s} 13280-011-0159-\mathrm{z}$

Spatz DR, Zilliacus KM, Holmes ND, Butchart SHM, Genovesi P, Ceballos G, Tershy BR, Croll DA. 2017. Globally threatened vertebrates on island with invasive species. Sci Adv 3: e1603080. DOI: $10.1126 /$ sciadv. 1603080 .

Srivastava S, Dvivedi A, Shukla RP. 2014. Invasive alien species of terrestrial vegetation of North-Eastern Uttar Pradesh. Int J For Res 2014: 1-9. DOI: $10.1155 / 2014 / 959875$.

Su W, Sun Q, Xia M, Wen Z, Yao Z. 2018. The resource utilization of water hyacinth (Eichhornia crassipes [Mart.] Solms) and its challenges. Resources 7 (3): 46. DOI: 10.3390/resources7030046.

Sudana IW, Mohamad I. 2020. Characteristics of Water hyacinth crafts Gorontalo. Dewa Ruci: Jurnal Pengkajian dan Penciptaan Seni 15 (1): 38-47. DOI: 10.33153/dewaruci.v15i1.3171. [Indonesian]

Sudhakar K, Ananthakrishnan R, Goyal A. 2013. Biogas production from a mixture of water hyacinth, water chesnut, and cow dung. Intl J Sci Eng Technol Res 2 (3): 35-37.

Sudjarwo T, Nisyawati, Rosiana N., Mangunwardoyo W. 2014. The growth of Water hyacinth (Eichhornia crassipes (Mart.) Solms) and Water lettuce (Pistia stratiotes L.) in domestic wastewater in wastewater treatment plant (WWTP) Bojongsoang, Bandung, Indonesia. J Biodiv Environ Sci 5 (4): 393-401.

Sulastri, Henny C, Handoko U. 2016. Environmental condition and trophic status of Rawapening Lake in Central Java. Oseanol Limnol Indones 1 (3): 23-38. DOI: 10.14203/oldi.2016.v1i3.20. [Indonesian]

Sutadian AD, Muttila N, Yilmazd AG, Pereraa BJC. 2017. Development of a water quality index for rivers in West Java Province, Indonesia. Ecol Indic 85: 966-982. DOI: 10.1016/j.ecolind.2017.11.049.

Tanner R, Branquart E, Brundu G, Buholzer S, Chapman D, Ehret P, Fried G, Starfinger U, van Valkenburg J. 2017. The prioritization of a shortlist of alien plants for risk analysis within the framework of the regulation (EU) No. 1143/2014. NeoBiota 35: 87-118. DOI: 10.3897/neobiota.35.12366.

Thapa S, Chitale V, Rijal SJ, Bisht N, Shrestha BB. 2018. Understanding the dynamics in distribution of invasive alien plant species under predicted climate change in Western Himalaya. PLoS ONE 13 (4): 116. DOI: 10.1371 /journal.pone.0195752.

Thiele J, Isermann M, Kollmann J, Otte A. 2011. Impact scores of invasive plants are biased by disregard on environmental co-variation and non-linearity. NeoBiota 10: 65-79. DOI: 10.3897/neobiota.10.1191.

Ting WHT, Tan IAW, Salleh SF, Wahab NA. 2018. Application of water hyacinth (Eichhornia crassipes) for phytoremediation of ammoniacal nitrogen: A review. J Water Process Eng 22: 239-249. DOI: 10.1016/j.jwpe.2018.02.011

Tollington S, Turbe A, Rabitsch W, Groombridge JJ, Scalera R, Essl F, Shwartz A. 2015. Making the EU legislation on invasive species a conservation success. Conserv Lett 10 (1): 112-120. DOI: 10.1111/conl.12214.

Turbelin AJ, Malamud BD, Francis RA. 2017. Mapping the global state of invasive alien species: Patterns of invasion and policy responses. Glob Ecol Biogeogr 26 (1): 78-92. DOI: 10.1111/geb.12517.

UNDP. 2015. Human Development Report. United Nations Development Programme, New York.

UNEP. 1999. Technology Needs for Lake Management in Indonesia: Case Studies, Lakes Rawadanau and Rawapening Lake, Java. 1st Ed. UNEP International Environmental Technology Centre, Osaka. [Japan]

Utomo AW. 2016. Knitting life from Bengok patterns of utilization of Bengok (water hyacinth) around Rawapening Lake in the perspective of sustainable development. Jurnal Cakrawala 5 (2): 191-216. [Indonesian] 
Uwadiae RE, Okunade GO, Okosun AO. 2011. Community structure, biomass and density of benthic phytomacrofauna communities in a tropical lagoon infested by water hyacinth (Eichhornia crassipes). Pan-Am J AquatSci 6 (1): 44-56.

van Wilgen NJ, Richardson DM. 2012. The roles of climate, phylogenetic relatedness, introduction effort, and reproductive traits in the establishment of non-native reptiles and amphibians. Conserv Biol 26 (2): 267-277. DOI: $10.1111 / \mathrm{j} .1523-1739.2011 .01804 . x$

Van Wilgen BW, de Lange WJ. 2011. The costs and benefits of biological control of invasive alien plants in South Africa. Afr Entomol 19 (1) 504-514. DOI: 10.4001/003.019.0228.

Venter N, Hill M, Hutchinson S, Ripley B. 2012. Weevil-borne microbes contribute as much to the reduction of photosynthesis in water hyacinth as does herbivory. Biol Control 64 (2): 138-142. DOI: 10.1016/j.biocontrol.2012.10.011.

Verma R, Sivappa. 2017. Calculating growth rate of Water hyacinth pollution wise (in relation to trophic state). Intl J Eng Tech Res 7 (7): 85-90.

Vilà M, Espinar JL, Hejda M, Hulme PE, Jarosik V, Maron JL, Pergl J, Schaffner U, Sun Y, Pyšek P. 2011. Ecological impacts of invasive alien plants: A meta-analysis of their effects on species, communities and ecosystems. Ecol Lett 14 (7): 702-708. DOI: 10.1111/j.14610248.2011.01628.x.

Vilà M, Hulme PE. 2017. Impact of Biological Invasions on Ecosystem Services. Springer International, Cham. DOI: 10.1007/978-3-31945121-3.

Villamagna AM, Murphy BR. 2010. Ecological and socio-economic impacts of invasive water hyacinth (Eichhornia crassipes): a review. Freshw Biol $55 \quad$ (2): 282-298. DOI: 10.1111/j.13652427.2009.02294.x.

Wang Z, Zhang Z, Zhang J, Zhang Y, Liu H, Yan S. 2012. Large scale utilization of water hyacinth for nutrient removal in lake Dianchi in China: The effect on the water quality, macrozoobenthos and zooplankton. Chemosphere 89 (10): 1255-1261. DOI: 10.1016/j.chemosphere.2012.08.001.

Wanyonyi WC, Onyari JM, Shiundu PM. 2014. Adsorption of Congo red dye from aqueous solutions using roots of Eichhornia crassipes: Kinetic and equilibrium studies. Energy Procedia 50: 862-869. DOI: 10.1016/j.egypro.2014.06.105.

Westerdahl HE, Getsinger KD. 1988. Aquatic plant identification and herbicide use guide, volume II: Aquatic plants and susceptibility to herbicides. Technical Report A-88-9. Department of the Army Waterways Experiment Station, Corps of Engineers, Vicksburg, MS. DOI: $10.21236 / A D A 203243$.

Williams A, Hecky R, Duthie H. 2007. Water hyacinth decline across Lake Victoria-Was it caused by climatic perturbation or biological control? A reply. Aquatic Bot 87 (1): 94-96. DOI: 10.1016/j.aquabot.2007.03.009.

Witte F, Silsbe G, Hecky R, Goudswaard P, Guildford S, Kishe-Machumu M, Wanink J. 2012. Did the loss of phytoplanktivorous fish contribute to algal blooms in the Mwanza Gulf of Lake Victoria? Hydrobiologia 679 (1): 283-296. DOI: 10.1007/s10750-011-0893-z.

Worqlul AW, Ayana EK, Dile YT, Moges MA, Dersseh MG, Tegegne G, Kibret S. 2020. Spatiotemporal dynamics and environmental controlling factors of the Lake Tana water hyacinth in Ethiopia. Remote Sens 12 (17): 2706. DOI: 10.3390/ rs12172706.

Wuryanta A, Paimin. 2012. Rawapening Lake sedimentation analysis using Remote Sensing Technology and Geographic Information Systems. Proceedings of the VI National Seminar on Limnology 4: 523-534. [Indonesian]

Yan SH, Song W, Guo JY. 2017. Advances in management and utilization of invasive Water hyacinth (Eichhornia crassipes) in aquatic ecosystems - A review. Crit Rev Biotechnol 37 (2): 218-228. DOI: 10.3109/07388551.2015.1132406.

Yonathan A, Prasetya AR, Pramudono B. 2012. Biogas production from water hyacinth (Eichhornia crassipes): Study of consistency and ph on biogas produced. Jurnal Teknologi Kimia and Industri 1: 412-416. [Indonesian]

Yunindanova MB, Supriyono, Hertanto BS. 2020. Processing of invasive Water hyacinth weeds into market-worthy organic fertilizers as a solution to the dizziness swamp problem. PRIMA 4 (2): 78-87. DOI: 10.20961/prima.v4i2.42053.

Zan F, Huo S, Xi B, Li Q, Liao H, Zhang J. 2011. Phosphorus distribution in the sediments of a shallow eutrophic lake, Lake Chaohu, China. Environ Earth Sci 62 (8): 1643-1653. DOI: 10.1007/s12665-0100649-5.

Zhang ZH, Guo JY. 2017. Biology of water hyacinth. In: Yan SH, Guo JY (eds) Water Hyacinth: Environmental Challenges, Management, and Utilization. CRC Press, Boca Raton, FL. 